\title{
LAMENTATIONS 1:8A IN THE WORDINGS OF THE MASORETIC TEXT AND 4QLAM
}

\author{
Gideon R Kotzé \\ Ancient Studies \\ Stellenbosch University
}

\begin{abstract}
This study takes as its point of departure the view that 4QLam, one of the manuscripts of Lamentations from Qumran, holds great significance for both textcritics and exegetes who study Lamentations. To illustrate the significance of the manuscript, this study analyses the wordings of Lamentations 1:8 in 4QLam and the Masoretic text text-critically and provides interpretive comments on the differences between the two Hebrew textual representatives. In this regard, the study focuses on the variant readings לנידה לנוד
\end{abstract}

Key Words: 4QLam, Masoretic Text, Dead Sea Scrolls, Textual Criticism, Moral Impurity

\section{Introduction}

Since the discovery of the first Dead Sea scrolls in 1947 more than 200 manuscripts of the writings included in the Hebrew Bible have been found in the eleven caves at Qumran and other sites in the Judaean desert. ${ }^{1}$ Four of these manuscripts are scrolls of Lamentations. Caves 3 and 4 contained one Lamentations manuscript each (3QLam and 4QLam), while two Lamentations manuscripts were recovered from cave $5\left(5 \mathrm{QLam}^{\mathrm{a}}\right.$ and $\left.5 \mathrm{QLam}{ }^{\mathrm{b}}\right)$. The two fragments of 3QLam preserve individual words from Lamentations 1:10-12 and Lamentations 3:53-62. ${ }^{2}$ QLam $^{\mathrm{a}}$ presents portions of the fourth and fifth chapters of Lamentations: Lamentations 4:5-8 (fragment 1 column I); Lamentations 4:11-15 (fragment 1 column II); Lamentations 4:15-20 (fragment 1 column III); Lamentations 4:20-5:3 (fragment 1 column IV); Lamentations 5:4-12 (fragment 1 column V); and Lamentations 5:12-17 (fragment 1 column VI). ${ }^{3}$ The other manuscript from cave 5 exists only in one fragment with words from Lamentations $4: 17-20 .{ }^{4} 4 \mathrm{QLam}$ is the largest of the four

1. The ages of the scriptural manuscripts among the Dead Sea scrolls range from the third century BCE to the second century CE (Tov 2010:151-155). They are, therefore, the oldest textual representatives of the Hebrew Bible writings in the original languages and provide invaluable evidence for (1) the shape of these documents as they circulated in the centuries immediately before and after the turn of the common era; (2) the composition and transmission of the scriptural writings (Ulrich 2010:209-225); and (3) the practices employed by scribes in the production of the scrolls (Tov 2004). The Qumran discoveries in particular have supplied text-critics with new data concerning the textual history of the writings of the Hebrew Bible. At the same time, the data have led to shifts in the aims and procedures of textual criticism. On these matters, see, for example, Hendel (2010:281-302); Van der Kooij (2002:167-177); Tov (2012).

2 Cf. Baillet (1962:95). The manuscript was unruled and seems to have been arranged stichographically (Tov 2004:168, 170). It is dated to the period between $30 \mathrm{BCE}$ and $68 \mathrm{CE}$ on the basis of its Herodian script (Webster 2002:421).

3 Cf. Milik (1962a:174-177). This manuscript was not ruled or written in cola. Its late Herodian script allows it to be dated to the middle of the first century CE (Webster 2002:432).

4 Cf. Milik (1962b:177-178). To judge from the arrangement of the words that have survived on the manuscript, this scroll was written stichographically with two bicola per line (Tov 2004:168, 170). Milik (1962b:177) 
Lamentations manuscripts from Qumran. Three unruled columns of writing are preserved on three of its fragments. Together these three columns present portions of Lamentations 1:1-18. A few words of Lamentations 2:5 appear on the fourth small fragment from a later part of the same scroll.

The importance of these four Qumran manuscripts for the study of the text and content of Lamentations should not be underestimated. ${ }^{5}$ 4QLam, in particular, is important for both exegesis and textual criticism. ${ }^{6}$ The wording of Lamentations 1:1-18 in this manuscript often diverge from the wording of the MT. ${ }^{7}$ These variant readings include orthographical variants, ${ }^{8}$ individual textual variants (scribal changes to wording and scribal errors), as well as isolated 'interpretative insertions'. The result is that the content of the verses from Lamentations 1 in 4QLam are sometimes very different from the content of these verses in the MT. This fact should be of special interest to the exegete (Kotzé 2011:605-607). 4QLam also holds great value for the text-critic, because it preserves a number of readings that are more original than the readings in the Masoretic text (MT) and opens new vistas on the readings in the ancient translations of Lamentations. The purpose of this study is to illustrate the significance of 4QLam for the text-critic and the exegete by means of an analysis of the wording of Lamentations 1:8, and the first bicolon in particular, as it is represented by the Qumran manuscript and the MT. The analysis will, first, provide a transcription and translation of the two Hebrew textual representatives of the verse. This is followed by introductory comments on the differences between 4QLam and the MT. The wordings of Lamentations 1:8a in the MT and 4QLam will subsequently be subjected to a brief text-critical examination. In this regard, the reading לנוד in 4QLam and its counterpart in the MT, לנידה, are singled out for closer investigation. The analysis will conclude with interpretive comments on how these variant readings affect the content of the bicolon in the two Hebrew versions.

\section{Lamentations 1:8 in the Masoretic Text and 4QLam}

4QLam

Fragment 2 Column II lines 5-7

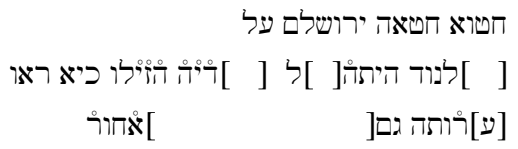

points out that the handwriting of $5 \mathrm{QLam}{ }^{\mathrm{b}}$ is of the same type as that of $5 \mathrm{QLam}{ }^{\mathrm{a}}$. Nevertheless, the same scribe did not copy both manuscripts.

5 For a text-critical evaluation of the four Lamentations manuscripts from Qumran, see Schäfer (2000:127-147).

${ }^{6}$ This view is corroborated by a recent study on the wordings of Lamentations 1:7 in 4QLam and the MT (Kotzé 2011:590-611).

7 The differences in wording between 4 QLam and the MT are summarised in an appendix at the end of this study.

8 According to Cross (2000:229), the orthography of 4QLam is of a "late 'full' Palestinian type that began to develop in Maccabaean times and continued in use into the Herodian era". Tov (2004:339), however, indicates that this manuscript shares the morphological and orthographic peculiarities that are characteristic of what he labels the 'Qumran scribal practice'. On the orthographic and morphological features of the Qumran scribal practice, see Tov (2004:266-270).

$9 \quad$ Ulrich (2010:219) defines these insertions as follows: "Learned scribes occasionally inserted into the text they were copying additional material that they considered valuable ... We could envision these insertions as marginal readings, footnotes, helpful or pious thoughts, chronological updates, etc., now entered into the text”. 
Jerusalem sinned greatly, there[fore]

[ ] she became a 'wanderer'. [ ] who [ ]her despised, because they saw

her [nak]edness. Also [ ] away.

MT

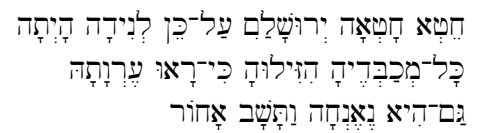

Jerusalem sinned greatly; therefore she became (morally) impure.

All those who honour her despised her because they saw her nakedness.

She also groans and turned away.

Apart from the orthographical variants, the wording of Lamentations 1:8 preserved in 4QLam exhibits three differences when compared to the wording of the MT (as represented by Codex Leningradensis). In the manuscript from Qumran, the opening word, חטוא, has the form of an infinitive absolute, while in the MT, it is taken as a noun, which constitutes an internal object (figura etymologica) with the verb חטאה. Since both the infinitive absolute and the internal object serve to 'strengthen the verbal idea' (Gesenius, Kautzsch and Cowley 1910:367), the meaning of the initial clause of Lamentations 1:8 (an emphasis on the severe nature of Jerusalem's $\sin )^{10}$ is similar in the two Hebrew versions of the verse. ${ }^{11}$ The MT contains the reading לנידה היתה, whereas the corresponding wording in 4QLam reads לנוד היתה This is an important variant, because לנירה might very well be more original than its counterpart in the MT (see below). The third difference between the wordings of this verse in the MT and 4QLam is found in the second bicolon. Even though ink traces are all that are left of the first three letters of the verb in 4QLam, the final waw is clearly visible on the manuscript. This means that the word was written without the third-person feminine pronominal suffix (cf. הזילוה in the MT). There does not seem to be anything in the vicinity of the reading that could have caused the scribal error. The minus of the suffix therefore strikes me as an accidental omission. Perhaps the scribe that copied 4QLam, or a predecessor, simply suffered a lapse in concentration. ${ }^{12}$

The following analysis focuses on the second of these three differences in wording of the MT and the Qumran manuscript. After an overview of the different interpretations of the difficult reading לנידה in the MT, the analysis will examine the ancient translations and determine whether the reading לנוד 4QLam sheds light on any of the translation equivalents. The analysis will subsequently indicate how לנידר in the MT could have developed from לנוד and, therefore, why the reading preserved in 4QLam qualifies as the original text.

10 With regard to the infinitive absolute in 4QLam Lamentations 1:8, the narrator asserts that Jerusalem sinned. The factuality of this claim is assumed (cf. Lamentations 1:5) and therefore the infinitive absolute describes the intensity of the action.

11 Schäfer (2004:55) characterises חטוא 4 in 4Qam as an assimilation to the standard form of the expression in Biblical Hebrew, but Hobbins (2006:19) argues that it is the lectio difficilior and semantically more suitable than the reading

12 It is possible that the manuscript from which 4 QLam was copied already contained the reading without the suffix. It should be noted, however, that there are a few scribal errors in 4QLam that probably originated with the copyist of this manuscript. These include dittography, wrong word division and minuses. At Lamentations 1:6, the negative particle לוא is written twice and the scribe copied מצא ומרעה as מצאו מרעה. Homoioteleuton was responsible for the lack of the words לה ראוה 4QLam's wording of Lamentations 1:7 and the long minus at Lamentations 1:10-11 (the words בקהל לך כל עמה נאנחים מבקשים לחם נתנות are missing from 4QLam). 
לנידה in the Masoretic Text and לנוד in a Text-Critical Analysis ${ }^{13}$

נידה in the MT is a hapax legomenon. It has elicited different interpretations from scholars. Some text-critics ${ }^{14}$ and commentators ${ }^{15}$ see נידה as a spelling variant of נדה (menstrual impurity'/'impure thing'/'abomination'). ${ }^{16}$ Proponents of this view often refer to words and images in the immediate context to substantiate their interpretation of נידה. Provan (1991:44), for example, mentions ערותה ('her nakedness') in verse 8b and ('מאתה ('her impurity') in verse 9a as two terms in the vicinity of "which are used elsewhere in the $O T$, often closely associated with niddāh, in statements about ritual cleanness and uncleanness" (italics in the original). In his opinion, the prohibition in Leviticus 18:19 is of particular interest in this regard, because all three words (טמאה ערה ) ערוה ) ערוה ) appear in this passage: "You shall not approach a woman to uncover her nakedness (ערותה) while she is in the impurity of her uncleanness (בנדת טמאתה)". These associations give rise to the view that Lamentations 1:8a portrays the personified city of Jerusalem as a menstruating woman in her state of ritual impurity. ${ }^{17}$ The main objection against such an interpretation is that it creates a problematic link between the ritual impurity of a woman in her period and sin. The opening bicolon of MT Lamentations 1:8 states that Jerusalem sinned greatly and that this is the reason why she became נידה. Berlin (2002:54-55) points out that menstruation causes a woman to become ritually, but not morally impure. Furthermore, a state of ritual uncleanness is not brought about by sin. Berlin therefore argues that נידה in the MT should be derived from the root נוד in its meaning 'to wander'. Accordingly, she translates Lamentations 1:8a as follows: "Grievously has Jerusalem sinned, therefore has she been banished" (Berlin 2002:42). Salters (2010:61) remarks that such an interpretation does not fit the context of the verse and Boase (2006:176) thinks that the images of shame, being despised by others, nakedness and impurity in verses 8-9 rule out Berlin's suggested interpretation. Parry (2010:51) also regards this interpretation as suspect and notes that it is the people of Jerusalem who are banished and go into exile, not the personified city.

Several scholars propose a third interpretation of גידה. Like Berlin, they relate to this word to נוד. However, they ascribe a different meaning to the verbal root. In addition to its sense of 'to wander', נוד can mean 'to waver', 'to shake' and 'to move to and fro'. ${ }^{18}$ In נוד 48:27 and Psalm 64:9, the hiphil and hithpolel forms of express the idea of shaking the head as a mocking (or sympathetic) gesture. The phrase ראש מנוד in Psalm 44:15 has a similar meaning ('object of head-nodding'). Those scholars who advocate the third interpretation of נידה suggest that it should be understood along these

13 The analysis follows an approach to textual criticism in which the various textual representatives of a Hebrew Bible writing are treated as witnesses to the content of the writing. This approach stresses the analytical aspect of the text-critical procedure insofar as its main aim is to determine how the readings in the textual representatives were created during the processes of transmission (copying and translation). For the purposes of the analysis, the following editions of textual representatives are used: 4QLam: Cross (2000:229-237); MT: Biblia Hebraica Quinta (Schäfer 2004:54-72, 113*-136*), Biblia Hebraica Stuttgartensia (Elliger and Rudolph 1977) and the third edition of Kittel's Biblia Hebraica (Kittel 1937); Septuagint: Ziegler (1976) and Rahlfs (2006); Peshitta: Albrektson (1963); Vulgate: Weber (2007); Western recension of Targum: Levine (1976); Yemenite recension of Targum: Van der Heide (1981).

14 Delitzsch (1920:35); Albrektson (1963:63-64).

15 Salters (2010:61); House (2004:334); Renkema (1998:133-134); Provan (1991:44-45); Haller (1940:96); Budde (1898:80-81); Keil (1872:564).

16 Brown, Driver and Briggs (1906:622); Koehler and Baumgartner (1958:96-597).

17 According to Exum (1995:257 n. 20), "The association with 'menstruous woman' is hard to miss, especially in view of the reference to ritual uncleanness in v. 9".

18 Brown, Driver and Briggs (1906:626); Koehler and Baumgartner (1958:600). 
lines. The text would then indicate that Jerusalem became an object of derision as a result of her great sin. ${ }^{19}$ Even though this interpretation of נידה can boast the support of the mediaeval Jewish exegete Ibn Ezra, other exegetes and modern-day critics remain unconvinced. $^{20}$

The ancient translations of Lamentations also exhibit a variety of different readings for

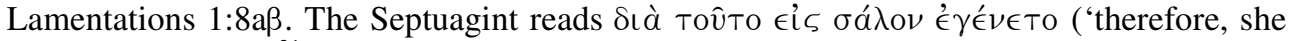
became unsteady'). ${ }^{21}$ If the Hebrew Vorlage of the Greek translation contained the reading נידה, the translator obviously related the hapax legomenon to in its sense of 'to move to and fro'/'to waver'. ${ }^{22}$ However, the fact that iוד is found in 4QLam raises the possibility that the Greek translator's Vorlage also contained this reading. ${ }^{23}$ The image in the Septuagint may hint at political instability. LXX Lamentations 1:8a would then imply that Jerusalem suffers the distress of political turmoil because of her sin. The Vulgate exhibits the same interpretation as the Greek translation: propterea instabilis facta est ('therefore, she has been made unsteady'). Jerome might have struggled with the hapax legomenon in his Hebrew text and translated with the help of the Septuagint or the Vetus Latina. ${ }^{24}$ The Aramaic translation in both the Western and Yemenite recensions of the Targum depicts Jerusalem as a wanderer (בטילטול הות). This means that נידה was derived from the root נוד (Alexander 2007:116). In the Peshitta, נהוא ('abomination') serves as translation equivalent for נידה in Lamentations 1:8 and נדה in Lamentations 1:17. The translator either interpreted נידה in verse 8 as a variant form of נדה, or the Hebrew Vorlage on which the Syriac translation was based contained this reading. The matter is moot, but Albrektson (1963:63) and Schäfer (2004:115*) share the view that the Syriac translator probably interpreted the reading in his Vorlage as a variant form of נדה. The reading ידה might also have been present in the Hebrew manuscripts used that were used by Aquila and Symmachus. Like the Peshitta, the translation equivalents in these versions witness to interpretations of נידה in accordance with meanings of נדה ${ }^{25}$ Furthermore, some of the mediaeval Masoretic

19 Cf. Berges (2002:89); Hunter (1996:127); Westermann (1994:112-113); Hillers (1992:70); Kraus (1983:29); Rudolph (1938:102); Perles (1922:85). Gordis (1974:155) thinks that it might have been the poet's intention to express both the meanings 'unclean' and 'object of scorn' by means of גידה. This suggestion presupposes that the form of the word that is found in Codex Leningradensis is the original reading.

20 Cf. the comments of Albrektson (1963:63-64). Rashi, another well-known Jewish interpreter, sees in נידה a reference to the exile (Salters 2010:60), while the midrash in Lamentations Rabbah 1:8 §35 explains נידה in terms of the root meaning 'to wander' (Cohen 1961:109).

21 Cf. A New English Translation of the Septuagint (NETS): "so she became ashaken" (Gentry 2007:936); La Bible d'Alenxandrie: "pour cela elle est devenue agitation" (Assan- Dhôte and Moatti-Fine 2005:200); and Septuaginta Deutsch: "deshalb ist sie ins Wanken geraten" (Hirsch-Luipold and Maier 2009:1350).

22 Cf. Hirsch-Luipold and Maier (2011:2832); and Assan-Dhôte and Moatti-Fine (2005:201).

23 Cf. Schäfer $\left(2004: 115^{*}\right)$ and Cross $(2000: 233 ; 1983: 141)$. Interestingly, 4QLam was copied at a time very close to the time usually posited for the translation of Lamentations into Greek. LXX Lamentations is generally dated to the middle of the first century BCE or the middle of the first century CE on the grounds that it forms part of the kaige group of translations and revisions (Hirsch-Luipold and Maier 2011:2831). Youngblood (2011:66) proposes that a "careful comparison of LXX Lamentations's translation technique with other members of the Kaige-Theodotion group, other non-Kaige translation units within the LXX tradition, and later revisers such as Aquila suggests that LXX Lamentations fits somewhere between 50 BCE and 100 CE”. 4QLam was written in a semi-formal Herodian script. Therefore, it is assigned a date between $30 \mathrm{BCE}$ and 1 CE (Webster 2002:412).

24 The Old Latin reading of Lamentations 1:8 is not recorded in Sabatier's edition (1743:724), but Assan-Dhôte notes that it follows the Septuagint and has the reading instabilis (Assan-Dhôte and Moatti-Fine 2005:201).

25 The versions attributed to Aquila and Symmachus are markedly different from the reading in LXX Lamentations. According to the readings recorded in the margin of the Syrohexapla (Ceriani 1874:140 [recto]), the version of Aquila reads حhrial ("therefore, [she became] one who is separated"). The 
manuscripts provide evidence that נידה was treated as a orthographical variant of נדה (1872:564) refers to manuscripts collated by Kennnicott that read לנדה instead of לנידה, while the critical apparatus of Kittel's Biblia Hebraica mentions eight Masoreteic manuscripts collected by Ginsberg that have the reading לְִָדָה at Lamentations 1:8 and not in MT Lamentations 1:17 the apparatus of Biblia Hebraica also indicates that five of Kennicott's manuscripts have the variant reading לנידה. With regard to Lamentations 1:8, it seems that a scribe changed the lectio difficilior לנידה into לנדה at some stage during the transmission history of the Hebrew text. ${ }^{26}$ In another copy, a scribe wrote לנידה instead of לנדה at Lamentations 1:17, possibly under the influence of the fuller spelling of the reading in verse 8 .

Turning to נוד in 4QLam, Cross (2000:233; 1983:141) argues cogently that this is a more original reading than נידה in the MT. This presupposes that the reading in the MT developed from the one witnessed to by the Qumran manuscript. First, Cross suggests that נידה ב בדה 1:17. Same into being under the influence ondly, the he at the end of נידה can be explained as a dittograph of the initial he of the next word, היתה. Thirdly, in the Hebrew scripts of the late Hasmonean and Herodian periods, the letters waw and yod look almost identical (cf. Cross 1961:138-139). The waw of might therefore have been mistaken for a yod: לנוד היתה In my opinion, this argument that לנידה in the MT developed through scribal errors from the original reading לבוד, which is found in 4QLam, provides the best explanation of the variants in the two Hebrew textual representatives of Lamentations 1:8. Therefore, the text-critical analysis of the textual representatives of Lamentations 1:8a demonstrates that the wording of 4QLam can help to explain the difficult reading לנירה in the MT and brings a plausible source text

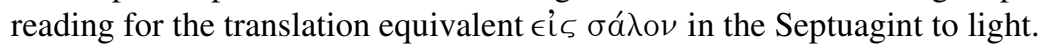

\section{An Interpretation of Lamentations 1:8a in the Masoretic Text}

The argument that לנידה developed from לנוד through scribal errors does not imply that later scribes could not make sense of this reading. This is evidenced by the change to לנדה in a

version of Symmachus seems to have a double reading: Rhe rheo ram ("because of this, [she

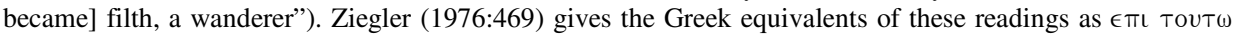

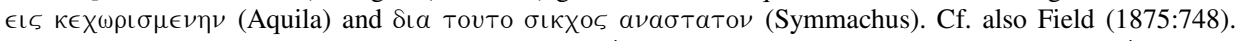
The reading of Aquila reflects an interpretation of לנידה that is similar to the Greek equivalent of לנדה in

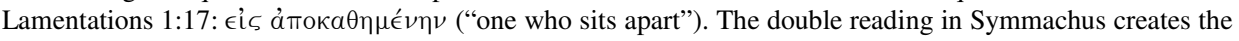
impression that the person who was responsible for this version vacillated between two possible interpretations of נירה.

26 This remark is based on the view that לגידה in the wording of the MT as represented by, inter alia, Codex Leningradensis, developed directly through scribal errors from an original reading לנוד (see below). On this interpretation of the textual evidence, the reading לנדה in some Masoretic manuscripts cannot be more original than לגירדה.

27 Schäfer $\left(2004: 115^{*}\right)$ agrees with Cross, but also mentions the possibility that לנוד 4 in 4 QLam might be a facilitation of the difficult word לנידה in the MT. Hobbins (2006:19) assumes that the readings in both 4QLam

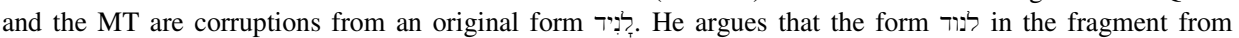
Qumran was created through a confusion of yod with waw, whereas לנידה resulted from dittography of he (or an aural error), as well as assimilation with לנדה in verse 17. Ilan (2008:9), however, argues that feminine metaphors in Lam 1 were replaced or removed in 4QLam and that the reading לנוד is an example of this. She also mentions other similar changes at Lam 1:13 and 1:17 in the manuscript from Qumran. The change of שומם to 4QLam's version of Lam 1:13 might indeed have been introduced deliberately by a scribe, but, in my opinion, לנדוח בגיהמה at Lam 1:17 in 4QLam can be attributed (at least partially) to scribal errors (cf. in the MT). 
number of MT manuscripts, as well as the ancient translations that probably had לנידה in their Vorlagen. The Peshitta, as well as the versions of Aquila and Symmachus show that at least some ancient interpreters brought meanings of נידה נידה Taking this association of the reading נידה מדה מדith as a point of departure, it will be proposed in what follows that some ancient readers might have understood נירה in the consonantal base of the MT's wording as a reference to the defilement caused by sin.

Research on the topic of purity and impurity in the Hebrew Bible and early Judaism stress the importance of distinguishing between two types of impurity, ritual and moral impurity. ${ }^{28}$ Ritual impurity is a temporary state of uncleanness which is highly contagious and arises from contact with certain natural (more or less unavoidable) processes and substances. This state disqualifies one from contact with sacred objects and can be removed by means of purification rites. In contrast to ritual impurity, moral impurity is generated through actions that are so loathsome as to be considered defiling. These actions include sexual sins, idolatry and bloodshed. Such deeds defile the person who commits them, the land of Israel, as well as the sanctuary of God. They are prohibited and not subject to rites of purification. ${ }^{29}$ Therefore, the language of impurity is used to refer to the effects of immoral, abominable actions on the sinner, the land and the Temple. ${ }^{30}$

The word נדה forms part of the impurity language in the Hebrew Bible and early Judaism. In the priestly material of the Torah $(\mathrm{P})$, it refers to the ritual impurity associated with a menstrual discharge (cf. Leviticus $12: 2,5 ; 15: 19,20,24,25,26,33 ; 18: 19) .{ }^{31}$ In biblical texts outside of $\mathrm{P}$, נרה is a general term for impurity or impure objects (cf. Ezekiel 7:19-20 and 2 Chronicles 29:5). However, it seems that נדה has the specific connotation of moral impurity in a few passages.

Leviticus 20:21, a passage from the holiness source in the Torah $(\mathrm{H})$, prohibits an Israelite man from 'taking' his brother's wife; that is, he is prohibited from having sexual intercourse with his sister-in-law. ${ }^{32}$ Such a deed is called מדה and it is identified as a

28 See the overview of this research compiled by Haber (2008:9-29), as well as the studies of Klawans (1997:116; 1995:285-312), Hayes (1999:3-36), Frymer-Kensky (1983:399-414) and Neusner (1975:15-26).

29 According to Klawans (1997:3), these actions "bring about an impurity that morally - but not ritually - defiles the sinner (Lev 18:24), the land of Israel (Lev 18:25; Ezek 36:17), and the sanctuary of God (Lev 20:3; Ezek 5:11). This defilement leads in turn to the expulsion of the people from the land of Israel (Lev 18:28; Ezek 36:19). Though the sinner's act defiles the land, the sinner does not defile those within his or her physical reach. There is no contact-contagion associated with moral impurity ... Moreover, there is no purification rite akin to those associated with ritual impurity: moral purity is achieved by punishment, atonement, or by refraining from committing morally impure acts in the first place".

30 Neusner $(1975: 20,24)$ speaks of the metaphorical use of purity language in connection with immoral, sinful deeds. However, Klawans (1997:5-6) argues convincingly that moral impurity is not metaphorical or figurative. This kind of uncleanness is just as real as ritual impurity (although it is a different sort of defilement). It brings about tangible consequences for sinners, the land and the sanctuary.

31 נדה derives either from נדר ('depart'/'flee'/'wander') or from the verbal root נדה ('chase away'/put aside'). Milgrom (1991:745) points out that, in the case of a menstruating woman, "originally referred to the discharge or elimination of menstrual blood, which came to denote menstrual impurity and impurity in general. In addition, niddâ came to refer not just to the menstrual discharge but to the menstruant herself, for she too was 'discharged' and 'excluded' from her society not by being kept at arm's length from others but, in many communities, by being banished to and quarantined in separate quarters". See also the discussion of Malul (2002:381-390).

32 Milgrom (2000:1758) interprets the verb לקח in the clause as a reference to marriage. This is also the interpretation witnessed to by the Vulgate and the Targum. However, לקח in verse 21 and in verses 14 and 17 should rather be understood in a sexual sense (Malul 2002:238; Gerstenberger 1996:288). 
punishable offence. ${ }^{33}$ Therefore, נדה here signifies an abhorrent act that causes the perpetrator to become morally unclean. ${ }^{34}$

In the penitential prayer of Ezra 9:6-15, ${ }^{35}$ Ezra confesses the present sin of the people in verses 10-12. He admits that the people trespass the commandments of YHWH spoken by the prophets by arranging for their children to marry foreigners. נדה appears twice in verse $11 .^{36}$ This verse declares that the land is morally defiled (מרץ נרה היא), because of the moral impurity (נדה), abominations (תועבת) and uncleanness (טמאה) of the 'peoples of the lands'.

Zechariah 13:1 is a third passage where נדה might denote the type of defilement caused by sin. It is used, together with the word ('sin'/'purification offering'), as the object of the unique cleansing function of the fountain (מקור) that will be opened for the house of David and the inhabitants of Jerusalem in an eschatological future time. In their illuminating comments on this difficult verse, Carol and Eric Meyers (1993:366) argue that חטאת , ובה , in combination with "provides a comprehensive conception of the state of pollution, caused by both moral wrongdoing and contaminating activity, that will be removed by the cosmic fountain in the future age". 38

33 Although it is not a capital crime, it will result in childlessness.

34 This interpretation of Leviticus 20:21 finds support from the ancient translations. In the Old Greek text of

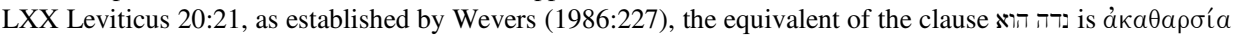

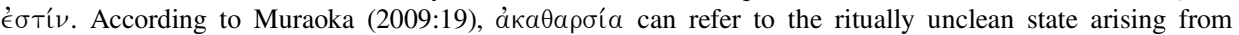
menstruation (cf. LXX Leviticus 15:24), immorality, moral or religious depravity, as well as a religiously or

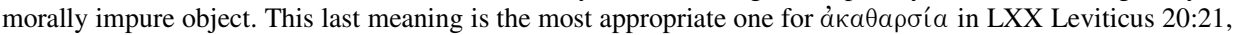
because it describes a person who commits a sexual offense (cf. Wevers 1997:325). Although נדה is usually rendered by حسم ('menstrual discharge') in the Peshitta text of Leviticus, at Leviticus 20:21 the Hebrew

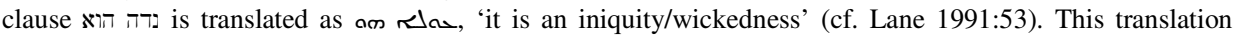
implies that the Syriac translator could interpret נדה in his Vorlage as having a religious or moral aspect to it and not only as a term for the ritual impurity caused by menstruation. In the Vulgate, it is said that he who marries his brother's wife does something that is not allowed (rem facit inlicitam). Grossfeld (1988:44) notes that the Aramaic word מרה in Targum Onqelos, Targum Neofiti and Targum PseudoJonathan, can be interpreted as an adjective, 'loathsome', which would be a value judgment on the marriage between a man and his sister-in-law. Alternatively, the reading can be read as a noun. In this case, the word refers to a woman who must be kept at a distance like a menstruating woman.

35 Werline (2006:xv) defines penitential prayer as "a direct address to God in which an individual, group, or an individual on behalf of a group confesses sins and petitions for forgiveness as an act of repentance". For a good discussion of Ezra 9:6-15 as a penitential prayer, see Duggan (2006:165-180).

36 Ezra 9:11 echoes a passage such as Leviticus 18:24-30 (Fensham 1982:131). In this passage, the people's impure and abominable deeds are responsible for the desecration of the land. The result of this defilement is their expulsion from the land.

37 Such an interpretation of the Hebrew wording of Ezra 9:11 is also found in the Greek text of 1 Esdras 8:80. According to the text in the edition prepared by Robert Hanhart (1974:132), the counterparts of the two

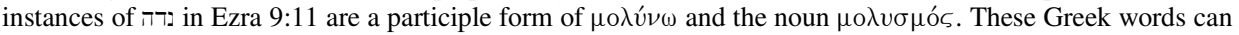
have the meaning of moral defilement (Muraoka 2009:466, 467). Conversely, the wording of the

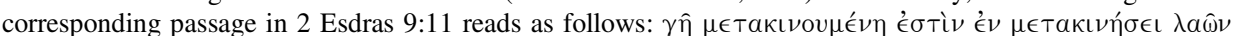
$\tau \hat{\omega} \nu \epsilon^{\epsilon} \theta \nu \hat{\omega} \nu$ (cf. Hanhart 1993:130). In NETS, the translation of this clause is "a land undergoing change by the changing of the nations" (Wooden 2007:412). The translator of 2 Esdras evidently did not understand נרה the sense of moral impurity.

38 It is also possible to understand נדה in Zechariah 13:1 as shorthand for the 'waters of lustration' (מדיה), which serve as a means of purification, especially in the case of contact with a corpse (cf. Numbers 19:9, 13, 20, 21

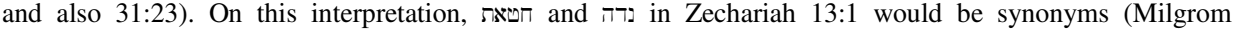
1991:745). The ancient translations bear witness to an interpretation of גדה in this verse that links it to the waters of lustration mentioned in the book of Numbers. The reading in the Peshitta text of Zechariah 13:1 is Rhuidla racoil (cf. Gelston 1980:89-90). Gelston (1987:136) identifies this reading as a possible case where the Syriac translation inverts a word pair in the Hebrew text of the Minor Prophets. This identification is based on the view that raoi ('ceremonial sprinkling'/'lustration') is a more likely translation equivalent for 
The language of purity and impurity is also used in the Dead Sea scrolls in connection with sin. ${ }^{39}$ Apart from its usual meanings, 2 appears in expressions that have to do with the impurity related to human imperfections and immorality. These expressions are found in writings of a variety of genres (rules, pesharim, poetic, sapiential and halakhic compositions). ${ }^{40}$ Moreover, this use of נדה does not seem to have been restricted to a particular community in early Judaism, because the writings among the Dead Sea scrolls in מדה has the sense of moral impurity include non-sectarian compositions, as well as the writings of the yahad.

The data culled from the Hebrew Bible, the ancient translations and the Dead Sea scrolls show that the term נדה sometimes refer to the impurity resulting from certain acts of wrongdoing. With regard to MT Lamentations 1:8a, it is quite possible that some ancient

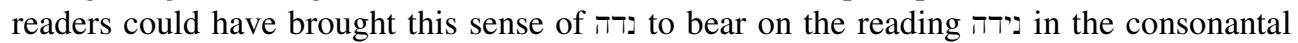
base of the MT. On such an interpretation of נידה, the words חטאה ירושלם על כן לנירה היתה make perfect sense, because Jerusalem's great sin is said to be the reason for her (moral) uncleanness.

\section{An Interpretation of Lamentations 1:8a in 4QLam}

Lamentations 1:7, 8 and the final part of verse 11 are well preserved in 4QLam. Unfortunately, very little of verses 9 and 10 survived. There is also a long minus in the wording of this manuscript compared the wording of the MT. The words from verse 10 are followed by מחמדיה באוכסל להשיב נפשה from verse 11. In addition to the minus, the wording of Lamentations 1:7-11 in 4QLam contain a number of readings that differ from their counterparts in the MT (see the appendix). The fragmentary nature of 4QLam at Lamentations 1:7-11, the long minus from verses 10 and 11, as well as the web of agreements and differences between 4QLam and other textual representatives, make it almost impossible to gain a clear picture of the content of these five verses as a whole in the Qumran manuscript. It is equally difficult to determine whether the variants in 4QLam form any kind of pattern that is specific to the wording of this manuscript. ${ }^{41}$ The following interpretive comments on 4QLam's wording of verse 8 must be seen against this background.

נדה The fording of the Targum of Zechariah 13:1 exhibits a similar inversion of word order. Furthermore, the water of lustration and the ashes of the red cow are explicitly mentioned in the Targum (Cathcart and Gordon 1989:220). Although there is no translation for לחטאת ולנדה in the original Greek text of Zechariah, the equivalents for נרדה in the Syrohexapla and the versions of Aquila and Symmachus are reoi

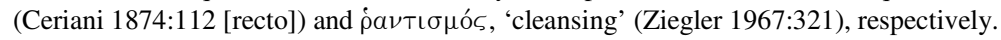

39 Cf. Klawans (2010:377-402; 1997:7-10); Haber (2008:47-71); Harrington (2000:610-616); Himmelfarb (2000:9-37).

40 Cf. 1QS column IV lines 5, 10, 22; column V line 19 (cf. also the parallel manuscripts 4Q256 column IX fragment 4 line 13 and 4Q258 column 1 fragment 1a, b line 11); column X line 24; column XI line 14; 1QM column XIII line 5; 1QpHab column VIII line 13; 1QH ${ }^{\mathrm{a}}$ column IV line 19; column V line 21; column IX line 11; column XX line 25; column XXI line 16; 4QH (4Q428) fragment 7 line 4; 4QpNah fragment 3 column III line 1; 4Q286 fragment 7 column II line 4; 4QapPs ${ }^{\mathrm{b}}$ (4Q381) fragment 46 line 6; fragment 69 line 2; 4Q419 fragment 1 line 11; 11QT column LXVI line 13; CD A column II line 1; column III line 17. In the following passages, the use of נדה is debatable or uncertain: 4Q181 fragment 1 column II line 2 (cf. Garcia Martínez and Tigchelaar 1997:373); 4Q374 fragment 2 column II line 3; 4Q507 fragment 1 line 3; 4Q511 fragment 2 column II line 8; fragment 18 column II line 7; 4Q512 fragment 36-38 line 6; fragment 29-32 line 9; fragment 1-3 line 9 .

41 It has been suggested elsewhere that a particular pattern can be discerned in the variant readings of verses 7 , 11 and 13 in 4QLam. See Kotzé (2011:601-602). 
The content of the third bicolon of the verse in $4 \mathrm{QLam}$ is uncertain, because of the lacuna in the manuscript. Cross (2000:232) reconstructs the missing text with the help of the MT: גם] היאה נאנחה ותשב [אחור [. If the gaps in the wording of the first two bicola of 4QLam are filled in accordance with the MT, 4QLam's text of Lamentations 1:8a-b states that Jerusalem sinned greatly (חטוא חטאה ירושלם) and that this is the reason she became נוד (נחכוד).

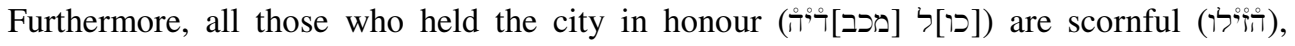
because they saw her 'nakedness' (לטיותה]).

With regard to the reading לנוד in 4QLam, two possible interpretations present themselves. ${ }^{42}$ On the one hand, it can be taken to mean '(object of) head-wagging'. On the other hand, נוד can be interpreted in its sense of 'to wander'. Despite the misgivings of Salters (2010:61), Parry (2010:51) and Boase (2006:176), the idea of wandering expressed by נוד carries with it at least two connotations that are quite appropriate in the context of Lamentations 1:8.

First, נוד can be associated with fleeing (Ringgren 1998:271). For example, in Jeremiah's oracle against Babylon (Jeremiah 50:3), the prophet announces that a nation from the north advances against Babylon and that it shall lay waste to the land so that no one shall live in it. The result is that both humans and animals take flight (נדכו) (הלכו). If this sense of the word is applied to לנוד היתה in 4QLam's wording of Lamentations 1:8a, the opening clause of the verse would mean that Jerusalem sinned greatly and therefore became a fugitive. The statement concerning Jerusalem's sin as the grounds for her fugitive status should be read together with the following clause, which mentions the city's 'nakedness', that is, her ruined condition. ${ }^{43}$ The personification of the city then works on two levels. It signifies the city's inhabitants in the first bicolon and the city as a physical entity in the second one. From this perspective, 4QLam's version of verse 8 implies that the city's destruction not only causes those who held her in great esteem to be contemptuous, but also led to the flight of her inhabitants. All of this is the consequence of the people's $\sin$.

Secondly, נוד can have the nuance of roving. It appears in this sense of 'homelessness' or 'unsettled wandering' together with the verb ('to be unstable'/'to be without a home') in the curse that YHWH pronounces against Cain for murdering his brother, Abel (Genesis 4:12): נע ונד תהיה בארץ ("you will be a fugitive and a rover on the earth"). According to Genesis 4:13-14, Cain recognises the "prospect of such a life of unrest and harassment without peace" as a punishment for his sin (Von Rad 1961:107). ${ }^{44}$ Therefore, in light of Genesis 4:12, 14, it is clear that being expelled from one's land and forced to take up the existence of a wanderer could have been considered as a divine punishment. With this

42 Interestingly, Abegg, Flint and Ulrich (1999:624) translate the reading in 4QLam as "one who shows grief".

43 The image of the city's 'nakedness' is open to more than one interpretation. Some interpreters see in the phrase ראו ערותה a reference to the rape of Lady Jerusalem (Boase 2006:176; Miller 2001:405; Baumann 2000:176-177), but Renkema (1998:134-135) argues that "ערותה is given concrete form in terms of despoilment and destruction which is equivalent to the removal of majesty and splendour. Where a city is concerned nakedness implies openness and vulnerability or lack of protection". Kraus (1983:29) gives a similar interpretation of the image. The use of the image of nakedness to picture the exposure of the invaded and destroyed city carries with it the connotation of shame and humiliation (O'Connor 2002:22).

44 In contrast to Ringgren (1997:271), who claims that this verse "characterizes the unsettled wandering of a nomad as divine punishment", Westermann (1974:419) emphasises the fact that the phrase נע ונד does not refer to a nomadic lifestyle. 
negative connotation of נוד in mind, Lamentations 1:8a in 4QLam can be taken to mean that Jerusalem became a wanderer as punishment for her great $\sin ^{45}$

\section{Conclusions}

This study on the different wordings of Lamentations 1:8a in the MT and 4QLam presents only a small sample of the available data. Nevertheless, it demonstrates that the Qumran manuscripts of Lamentations hold value for both the text-critic and the exegete.

On the one hand, לנוד 4Q 4Q original than its counterpart in the MT, but it also serves as a point of departure for explaining how the difficult reading in the MT came into being during the process of transmission. The analysis also suggests that the Hebrew Vorlage of the LXX might very well have contained a reading such as לנוד. The wording of Lamentations 1:8a in 4QLam therefore opens new perspectives on the readings in some of the textual representatives of Lamentations that were available before the Qumran discoveries.

On the other hand, the interpretive comments on the wordings of Lamentations 1:8a in the two Hebrew versions draw attention to the effect that the variant readings in these manuscripts have on the content of the bicolon.

Data of the kind provided by this study will be relevant to the interpretation of Lamentations if two conditions are met. First, the data must show that the differences in wording between the MT and the Qumran manuscript of Lamentations, which were created by scribes when they copied their manuscripts, affect the content of a passage. The differences in content pertain mostly to individual variants and rarely to the orthographical variants and scribal errors. Secondly, neither the textus receptus nor the putative original text should be treated as the only valid representative of the content of Lamentations. This means that the Qumran manuscripts of Lamentations should not only be examined in order to edit the wording of the MT in cases where the former preserve 'preferable' readings. Admittedly, 3QLam and 5QLam ${ }^{\text {b }}$ are too fragmentary to draw firm conclusions about the contents of Lamentations in these manuscripts. However, enough of the wordings of Lamentations 1 and Lamentations 4-5 have survived in 4QLam and 5QLam ${ }^{\text {a }}$ respectively to make analyses of the ways in which they present the contents of the chapters viable. The differences in content between the MT and these two Qumran manuscripts of Lamentation can only be ignored or dismissed as of secondary importance if scholars continue to privilege the wording of the MT or the presumed Hebrew Urtext in their exegetical efforts.

45 The name 'Jerusalem' is obviously used here metonymically to signify the inhabitants of the city. 


\section{Appendix}

The following list presents the variant readings in 4QLam when compared with the MT. It also indicates whether the readings in the ancient translations agree with one of these Hebrew versions. Furthermore, the readings in 4QLam are evaluated and categorised as more original than the MT (orig.), a scribal error (err.), a (deliberate) change in wording introduced by a scribe (scr.) or an interpretative insertion (int.). Orthographical variants are not recorded in the list. In cases where both 4QLam and the MT have a claim to being original, the readings are marked with an equals sign (=).

\begin{tabular}{|c|c|c|}
\hline Lam 1:6 & 4QLam MT qere [ מן בת MT kethib & $(=)$ \\
\hline Lam 1:6 & MT לא ] 4QLam לוא לוא & (err.) \\
\hline Lam 1:6 & MT LXX P V מצאו מרעה ] 4QLam מצא ומרעה & (err.) \\
\hline Lam 1:6 & MT LXX P בלא כח [ 4QLam בלי כוח & (orig.?) \\
\hline Lam 1:7 & 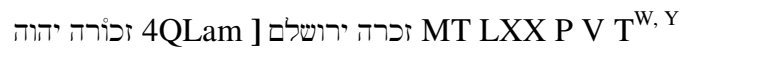 & (scr.) \\
\hline Lam 1:7 & MT LXX P V ] > 4QLam ימי עניה ומרודיה & (orig.) \\
\hline Lam 1:7 & MT LXX P V T T, y & (scr.) \\
\hline Lam 1:7 & MT LXX P T ${ }^{\mathrm{W}, \mathrm{Y}}$ ] > 4QLam & (err.) \\
\hline Lam 1:7 & 4QLam LXX P ] צרים MT V T T, Y & (orig.) \\
\hline Lam 1:7 & ל[ ] 4QLam ] > MT LXX P V & (err.?) \\
\hline Lam 1:7 & 4QLam P ] משבריה MT LXX V משבתה & (orig.) \\
\hline Lam 1:8 & חטא חטאה [QLam MT LXX P V T & $(=)$ \\
\hline Lam 1:8 & 4QLam LXX לנידה לנוד MT P a', c $^{\prime}$ & (orig.) \\
\hline Lam 1:8 & 4QLam ] הזילוה MT LXX P V T T, Y & (err.) \\
\hline Lam 1:9 & MT פלאים [ 4QLam [פ]לאות & (scr.) \\
\hline Lam 1:9 & 4QLam P T & (scr.?) \\
\hline Lam 1:10-11 & MT P V ] > 4QLam בקהל לך כל עמה נאנחים מבקשים לחם נתנו & (err.) \\
\hline Lam 1:11 & 4QLam LXX [ מחמודיהם MT P T & (scr.) \\
\hline Lam 1:11 & MT LXX P V & (scr.) \\
\hline Lam 1:11 & 4QLam [ זוללה MT LXX P V & (scr.) \\
\hline Lam 1:12 & MT P לוא אליכם [ 4QLam לוא אליכ[י] & (scr.) \\
\hline Lam 1:12 & 4QLam [ עלל לי MT P T & (scr.) \\
\hline Lam 1:12 & 4QLam ] הוגה MT הוגירני & (scr.) \\
\hline Lam 1:12 & MT LXX P V T T, Y & (orig.) \\
\hline Lam 1:13 & 4QLam P ] וירדנה MT & (scr.) \\
\hline Lam 1:13 & MT LXX P V T T , השיבני ] & (err.) \\
\hline
\end{tabular}




\begin{tabular}{|c|c|c|}
\hline Lam 1:13 & MT LXX P V T T, Y שוממה [4Lam שומם & (scr.) \\
\hline Lam 1:13 & MT LXX P V T T, & (scr.) \\
\hline Lam 1:14 & 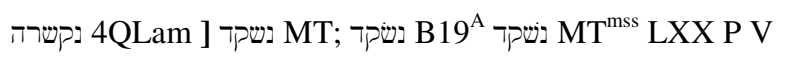 & (scr.) \\
\hline Lam 1:14 & ישתרגו [ MT LXX P V TW, Y & (scr.?) \\
\hline Lam 1:14 & MT LXX V T T, y & (orig.?) \\
\hline Lam 1:14 & 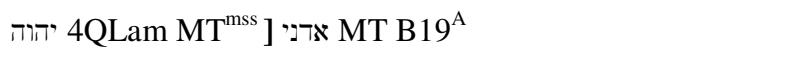 & (orig.?) \\
\hline Lam 1:14 & 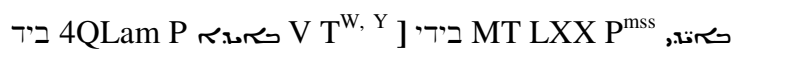 & $(=?)$ \\
\hline Lam 1:14 & MT קום ] 4QLam לקום & (scr.?) \\
\hline Lam 1:15 & MT LXX P V T T, y & (err.) \\
\hline Lam 1:15 & MT אדני [QLam M⿻iרה MT & (orig.?) \\
\hline Lam 1:16-17 & Different sequences: pe/ayin 4QLam - ayin/pe MT & $(=)$ \\
\hline Lam 1:17 & 4QLam ] > MT LXX P V & (int.) \\
\hline Lam 1:17 & MT LXX P V T T, Y צוה ] 4QLam צפה & (orig.) \\
\hline Lam 1:17 & MT ירושלם M 4QLam ציון & (scr.) \\
\hline Lam 1:17 & MT LXX P V T T, Y לנדה [4Lam לנדוח & (err.) \\
\hline Lam 1:16 & אני בוכיה עיני עיני ירדה ] MT P TW, Y & (scr.) \\
\hline Lam 1:16 & MT LXX P V T & (scr.) \\
\hline Lam 1:16 & MT LXX P V T T, Y & (err.) \\
\hline Lam 1:18 & MT יהוה [QLam א[דוני & (scr.?) \\
\hline
\end{tabular}

\section{BIBLIOGRAPHY}

Abegg, MG, Flint, PW and Ulrich, E 1999. The Dead Sea Scrolls Bible: The Oldest Known Bible Translated for the First Time into English. San Francisco: HarperSanFrancisco.

Albrektson, B 1963. Studies in the Text and Theology of the Book of Lamentations: With a Critical Edition of the Peshitta Text. Lund: CWK Gleerup.

Alexander, PS 2007. The Targum of Lamentations. Translated, with a Critical Introduction, Apparatus, and Notes. The Aramaic Bible 17B. Collegeville: Liturgical Press.

Assan-Dhote, I and Moatti-Fine, J 2005. Baruch, Lamentations, Lettre de Jérémie. La Bible d'Alexandrie 25.2. Paris: Cerf.

Baillet, M 1962. Lamentations. In Les 'Petites Grottes' de Qumran. Exploration de la Falaise, Les Grottes 2Q, 3Q, 5Q, 6Q, 7Q à 10Q, Le Rouleau de Cuivre, (eds.) M Baillet, JT Milik and R de Vaux, 95. Discoveries in the Judaean Desert III. Oxford: Clarendon Press. 
Baumann, G 2000. Liebe und Gewalt. Die Ehe als Metapher für das Verhältnis JHWH Israel in den Prophetenbüchern. SBS vol. 185. Stuttgart: Katholisches Bibelwerk.

Berges, U 2002. Klagelieder. HThKAT. Freiburg: Herder.

Berlin, A 2002. Lamentations. A Commentary. Old Testament Library. Louisville: Westminster/John Knox Press.

Boase E 2006. The Fulfilment of Doom? The Dialogic Interaction between the Book of Lamentations and the Pre-Exilic/Early Exilic Prophetic Literature. New York/London: Continuum.

Brown, F, Driver, S R \& Briggs, C A 1906. A Hebrew and English Lexicon of the Old Testament. Oxford: Oxford University Press.

Budde, K, Bertholet, A and Wildeboer, DG 1898. Die Fünf Megillot: Das Hohelied, das Buch Ruth, Die Klagelieder, Der Prediger, Das Buch Esther. KHAT. Tübingen: J.C.B. Mohr (Paul Siebeck).

Cathcart, KJ and Gordon, RP 1989. The Targum of the Minor Prophets. Translated, with a Critical Introduction, Apparatus, and Notes. The Aramaic Bible 14. Collegeville: Liturgical Press.

Ceriani, AM 1874. Codex Syro-Hexaplaris Ambrosianus photolithographice editus. Milan: Bibliothecae Ambrosianae.

Cohen, A 1961. Lamentations. In Midrash Rabbah, (eds.) H Freedman and M Simon. Vol. 7. London: Soncino Press.

Cross, FM 1961. The Development of the Jewish Scripts. In The Bible and the Ancient Near East: Essays in Honor of William Foxwell Albright, (ed.) GE Wright, 133-202. London: Routledge \& Kegan Paul.

Cross, FM 1983. Studies in the Structure of Hebrew Verse: The Prosody of Lamentations 1:1-22. In The Word of the Lord Shall Go Forth: Essays in Honor of David Noel Freedman, (eds.) CL Meyers and M O'Connor, 129-155. Winona Lake: Eisenbrauns.

Cross, FM 2000. 4QLam. In Qumran Cave 4 XI: Psalms to Chronicles, (eds.) E Ulrich et al., 229-237. Discoveries in the Judaean Desert XVI. Oxford: Clarendon Press.

Delitzsch, F 1920. Lese- und Schreibfehler im Alten Testament. Berlin/Leipzig: de Gruyter.

Duggan, MW 2006. Ezra 9:6-15: A Penitential Prayer within Its Literary Setting. In Seeking the Favor of God. Volume 1: The Origins of Penitential Prayer in Second Temple Judaism, (eds.) MJ Boda, DK Falk and RA Werline, 165-180. Atlanta: Society of Biblical Literature.

Elliger, K and Rudolph, W 1997. Biblia Hebraica Stuttgartensia. Stuttgart: Deutsche Bibelgesellschaft.

Exum, JC 1995. The Ethics of Biblical Violence against Women. In The Bible in Ethics. The Second Sheffield Colloquium, (eds.) JW Rogerson, M Davies and MD Carroll, 248-271. Sheffield: Sheffield Academic Press.

Fensham, FC 1982. The Books of Ezra and Nehemiah. NICOT. Grand Rapids: Eerdmans.

Field, F 1875. Origenis hexaplorum quae supersunt sive veterum interpretum graecorum in totum vetus testamentum fragmenta. Vol. 2. Oxford: Clarendon Press. 
Frymer-Kensky, T 1983. Pollution, Purification, and Purgation in Biblical Israel. In The Word of the Lord Shall Go Forth: Essays in Honor of David Noel Freedman, (eds.) CL Meyers and M O'Connor, 399-414. Winona Lake: Eisenbrauns.

García Martínez, F and Tigchelaar, EJC 1997. The Dead Sea Scrolls Study Edition. Vol. 1. Leiden/Grand Rapids: Brill/Eerdmans.

Gelston, A 1980. The Old Testament in Syriac According to the Peshita Version III, 4: Dodekapropheton. Leiden: Brill.

Gelston, A 1987. The Peshita of the Twelve Prophets. Oxford: Clarendon Press.

Gentry, PJ 2007. Lamentations. In A New English Translation of the Septuagint, (eds.) A Pietersma and BG Wright, 932-941. New York/Oxford: Oxford University Press.

Gerstenberger, ES 1996. Leviticus. A Commentary. Old Testament Library. Louisville: Westminster/John Knox Press.

Gesenius, W, Kautzsch, E and Cowley, AE 1910. Gesenius' Hebrew Grammar. Oxford: Clarendon Press.

Gordis, R 1974. The Song of Songs and Lamentations. A Study, Modern Translation and Commentary. New York: KTAV.

Grossfeld, B 1988. The Targum Onqelos to Leviticus and the Targum Onqelos to Numbers. Translated, with Apparatus, and Notes. The Aramaic Bible 8. Collegeville: Liturgical Press.

Haber, S 2008. 'They Shall Purify Themselves': Essays on Purity in Early Judaism, (ed.) A Reinhartz. Atlanta: Society of Biblical Literature.

Haller, M 1940. Die Klagelieder. HAT. Tübingen: JCB Mohr.

Hanhart, R 1974. Septuaginta. Vetus Testamentum Graecum VIII, 1: Esdrae I. Göttingen: Vandenhoeck \& Ruprecht.

Hanhart, R 1993. Septuaginta. Vetus Testamentum Graecum VIII, 2: Esdrae II. Göttingen: Vandenhoeck \& Ruprecht.

Harrington, HK 2000. The Nature of Impurity at Qumran. In The Dead Sea Scrolls. Fifty Years After Their Discovery. Proceedings of the Jerusalem Congress, July 20-25, 1997, (eds.) LH Schiffman, E Tov and JC VanderKam, 610-616. Jerusalem: Israel Exploration Society in Cooperation with The Shrine of the Book, Israel Museum.

Hayes, C 1999. Intermarriage and Impurity in Ancient Jewish Sources, HTR 92(1):3-36.

Hendel, RS 2010. Assessing the Text-Critical Theories of the Hebrew Bible after Qumran. In The Oxford Handbook of The Dead Sea Scrolls, (eds.) TH Lim and JJ Collins, 281-302. Oxford: Oxford University Press.

Hillers, DR 1992. Lamentations. A New Translation with Introduction and Commentary. Anchor Bible 7A. New York: Doubleday.

Himmelfarb, M 2001. Impurity and Sin in 4QD, 1QS, and 4Q512. Dead Sea Discoveries 8(1):9-37.

Hirsch-Luipold, R and Maier, CM 2009. Threnoi/Die Klagelieder. In Septuaginta Deutsch. Das griechische Alte Testament in deutscher Übersetzung, (eds.) W Kraus and M Karrer, 1349-1358. Stuttgart: Deutsche Bibelgesellschaft.

Hirsch-Luipold, R and Maier, CM 2011. Threnoi/Threni Seu Lamentationes/ Die Klagelieder. In Septuaginta Deutsch. Erläuterungen und Kommentare zum 
griechischen Alten Testament. Band II: Psalmen bis Daniel, (eds.) M. Karrer and W Kraus, 2827-2841. Stuttgart: Deutsche Bibelgesellschaft.

Hobbins, JF 2006. Lamentations 1-5: The Corpus Introduction. [Cited 4 August 2011]. http://ancienthebrewpoetry.typepad.com/ancient_hebrew_poetry/2006/05/index.html $1-38$.

House, PR 2004. Lamentations. Word Biblical Commentary 23B. Nashville: Thomas Nelson.

Hunter, J 1996. Faces of a Lamenting City. The Development and Coherence of the Book of Lamentations. Frankfurt am Main: Peter Lang.

Ilan, T 2008. Gender and Lamentations: 4Q179 and the Canonization of the Book of Lamentations. Lectio Difficilior 2:1-16.

Keil, CF 1872. Biblischer Commentar über den Propheten Jeremia und die Klagelieder. Leipzig: Dörffling \& Franke.

Kittel, R 1937. Biblia Hebraica. Stuttgart: Württembergische Bibelanstalt.

Klawans, J 1995. Notions of Gentile Impurity in Ancient Judaism. AJSR 20(2):285-312.

Klawans, J 1997. The Impurity of Immorality in Ancient Judaism. JJS 48(1):1-16.

Klawans, J 2010. Purity in the Dead Sea Scrolls. In The Oxford Handbook of The Dead Sea Scrolls, (eds.) TH Lim and JJ Collins, 377-402. Oxford: Oxford University Press.

Koehler, L and Baumgartner, W 1958. Lexicon in Veteris Testamenti Libros. Leiden: Brill

Kotzé, GR 2011. A Text-Critical Analysis of Lamentations 1:7 in 4QLam and the Masoretic Text. OTE 24(3):590-611.

Kraus, H-J 1983. Klagelieder (Threni). BKAT. Neukirchen-Vluyn: Neukirchener Verlag.

Lane, DJ 1991. The Old Testament in Syriac According to the Peshita Version I, 2: Leviticus. Leiden: Brill.

Levine, E 1976. The Aramaic Version of Lamentations. New York: Hermon Press.

Malul, M 2002. Knowledge, Control and Sex. Studies in Biblical Thought, Culture and Worldview. Tel Aviv: Archaeological Center.

Meyers, CL and EM Meyers 1993. Zechariah 9-14. A New Translation with Introduction and Commentary. Anchor Bible 25C. New York: Doubleday.

Milgrom, J 1991. Leviticus 1-16. A New Translation with Introduction and Commentary. Anchor Bible 3. New York: Doubleday.

Milgrom, J 2000. Leviticus 17-22. A New Translation with Introduction and Commentary. Anchor Bible 3A. New York: Doubleday.

Milik, JT 1962a. Lamentations (Premier Exemplaire). In Les 'Petites Grottes' de Qumran. Exploration de la Falaise, Les Grottes 2Q, 3Q, 5Q, 6Q, 7Q à 10Q, Le Rouleau de Cuivre, (eds.) M Baillet, JT Milik and R de Vaux, 174-177. Discoveries in the Judaean Desert III. Oxford: Clarendon Press.

Milik, JT 1962b. Lamentations (Second Exemplaire). In Les 'Petites Grottes' de Qumran. Exploration de la Falaise, Les Grottes 2Q, 3Q, 5Q, 6Q, 7Q à 10Q, Le Rouleau de Cuivre, (eds.) M Baillet, JT Milik and R de Vaux, 177-178. Discoveries in the Judaean Desert III. Oxford: Clarendon Press.

Miller, CW 2001. Reading Voices: Personification, Dialogism, and the Reader of Lamentations 1. BI 9(4):393-408. 
Muraoka, T 2009. Greek-English Lexicon of the Septuagint. Louvain/Paris/Walpole: Peeters.

Neusner, J 1975. The Idea of Purity in Ancient Judaism. JAAR 43(1):15-26.

O'Connor, KM 2002. Lamentations and the Tears of the World. Maryknoll: Orbis.

Parry, RA 2010. Lamentations. THOTC. Grand Rapids: Eerdmans.

Perles, F 1922. Analekten zur Textkritik des Alten Testaments. Neue Folge. Leipzig: Gustav Engel.

Provan, IW 1991. Lamentations. New Century Biblical Commentary. Grand Rapids: Eerdmans.

Rahlfs, A 2006. Septuaginta. Id est Vetus Testamentum graece iuxta LXX interpretes: Editio altera quam recognovit et emendavit Robert Hanhart. Stuttgart: Deutsche Bibelgesellschaft.

Renkema, J 1998. Lamentations. Historical Commentary on the Old Testament. Leuven: Peeters.

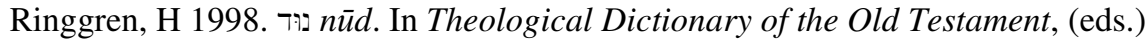
GJ Botterweck and H Ringgren, 271-272. Vol. IX. Grand Rapids: Eerdmans.

Rudolph, W 1938. Der Text der Klagelieder. ZAW 56:101-122.

Sabatier, P 1743. Bibliorum sacrorum latinae versions antiquae seu Vetus Italica et caeterae quaecunque in codicibus manuscriptis et antiquorum libris reperiri potuerunt: quae cum Vulgata Latina \& cum Textu Graeco comparantur. Vol. 2. Remis: Reginaldum Florentain.

Salters, RB 2010. Lamentations. International Critical Commentary. London: T\&T Clark.

Schäfer, R 2000. Der Masoretische Text der Klagelieder und die Handschriften 3QLam, 4QLam un 5QLam ${ }^{\text {a.b }}$ aus Qumran. In Die Textfunde vom Toten Meer und der Text der Hebräischen Bibel, (eds.) U Dahmen, A Lange and H Lichtenberger, 127-147. Neukirchen-Vluyn: Neukirchener Verlag.

Schäfer, R 2004. Lamentations. In Biblia Hebraica quinta editione cum apparatu critico novis curis elaborato: General Introduction and Megilloth, (eds.) A Schenker et al., 54-72, 113*-136*. Stuttgart: Deutsche Bibelgesellschaft.

Tov, E 2004. Scribal Practices and Approaches Reflected in the Texts Found in the Judean Desert. Leiden/Boston: Brill.

Tov, E 2010. Some Thoughts about the Diffusion of Biblical Manuscripts in Antiquity. In The Dead Sea Scrolls: Transmission of Traditions and Production of Texts, (eds.) S Metso, H Najman and E Schuller, 151-172. Leiden/Boston: Brill.

Tov, E 2012. Textual Criticism of the Hebrew Bible. Third Edition, Revised and Expanded. Minneapolis: Fortress Press.

Ulrich, E 2010. The Evolutionary Production and Transmission of the Scriptural Books. In The Dead Sea Scrolls: Transmission of Traditions and Production of Texts, (eds.) S Metso, H Najman and E Schuller, 209-225. Leiden/Boston: Brill.

Van der Heide, A 1981. The Yemenite Tradition of the Targum of Lamentations. Studia Post-Biblica 32. Leiden: Brill.

Van der Kooij, A 2002. The Textual Criticism of the Hebrew Bible Before and After the Qumran Discoveries. In The Bible as Book. The Hebrew Bible and the Judaean 
Desert Discoveries, (eds.) ED Hiebert and E Tov, 167-177. London/New Castle: British Library/Oak Knoll Press.

Von Rad, G 1961. Genesis. Old Testament Library. London: SCM Press.

Weber, R 2007. Biblia Sacra iuxta Vulgatam Versionem: Editionem quintam emendatam retractatam praeparavit Roger Gryson. Stuttgart: Deutsche Bibelgesellschaft.

Webster, B 2002. Chronological Index of the Texts from the Judaean Desert. In The Texts from the Judaean Desert. Indices and an Introduction to the Discoveries in the Judaean Desert Series, (ed.) E Tov, 351-446. Discoveries in the Judaean Desert XXXIX. Oxford: Clarendon Press.

Werline, RA 2006. Defining Penitential Prayer. In Seeking the Favor of God. Volume 1: The Origins of Penitential Prayer in Second Temple Judaism, (eds.) MJ Boda, DK Falk and RA Werline, xiii-xvii. Atlanta: Society of Biblical Literature.

Westermann, C 1974. Genesis 1-11. BKAT. Neukirchen-Vluyn: Neukirchener Verlag.

Westermann, C 1994. Lamentations. Issues and Interpretation. Minneapolis: Fortress Press.

Wevers, JW 1986. Septuaginta. Vetus Testamentum Graecum II, 1: Leviticus. Göttingen: Vandenhoeck \& Ruprecht.

Wevers, JW 1997. Notes on the Greek Text of Leviticus. Society of Biblical Literature Septuagint and Cognate Studies 44. Atlanta: Scholars Press.

Wooden, RG 2007. 2 Esdras. In A New English Translation of the Septuagint, (eds.) A Pietersma and BG Wright, 405-423. New York/Oxford: Oxford University Press.

Youngblood, KJ 2011. The Character and Significance of LXX Lamentations. In RA Parry and HA Thomas (eds.), Great Is Thy Faithfulness? Reading Lamentations as Sacred Scripture, (eds.) RA Parry and HA Thomas, 64-69. Eugene: Pickwick.

Ziegler, J 1967. Septuaginta. Vetus Testamentum Graecum XIII: Duodecim prophetae. Göttingen: Vandenhoeck \& Ruprecht.

Ziegler, J 1976. Septuaginta. Vetus Testamentum Graecum XV: Jeremias, Baruch, Threni, Epistula Jeremiae. Göttingen: Vandenhoeck \& Ruprecht. 